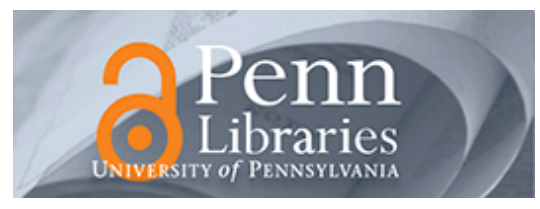

University of Pennsylvania

ScholarlyCommons

Accounting Papers

Wharton Faculty Research

8-2010

\title{
Are Individuals Entering Self-Employment Overly Optimistic? An Empirical Test of Plans and Projections on Nascent Entrepreneur Expectations
}

Gavin Cassar

University of Pennsylvania

Follow this and additional works at: https://repository.upenn.edu/accounting_papers

Part of the Accounting Commons, and the Business Administration, Management, and Operations Commons

\section{Recommended Citation}

Cassar, G. (2010). Are Individuals Entering Self-Employment Overly Optimistic? An Empirical Test of Plans and Projections on Nascent Entrepreneur Expectations. Strategic Management Journal, 31 (8), 822-840. http://dx.doi.org/10.1002/smj.833

This paper is posted at ScholarlyCommons. https://repository.upenn.edu/accounting_papers/48

For more information, please contact repository@pobox.upenn.edu. 


\title{
Are Individuals Entering Self-Employment Overly Optimistic? An Empirical Test of Plans and Projections on Nascent Entrepreneur Expectations
}

\author{
Abstract \\ This research examines the rationality of the expectations of nascent entrepreneurs. Consistent with \\ conjectures regarding entry into self-employment, I find substantial overoptimism in nascent \\ entrepreneurs' expectations, in that they overestimate the probability that their nascent activity will result \\ in an operating venture. Further, for those ventures that achieve operation, individuals overestimate the \\ expected future sales and employment. To explain variations in overoptimism, I posit that those \\ individuals who adopt an inside view to forecasting through the use of plans and financial projections, will \\ exhibit greater ex ante bias in their expectations. Consistent with the inside view causing overoptimism in \\ expectations, I find that the preparation of projected financial statements results in more overly optimistic \\ venture sale forecasts. Copyright @ 2010 John Wiley \& Sons, Ltd.
}

\section{Keywords}

expectations, final projections, forecasting, nascent entrepreneur, overoptimism, planning, rationality

\section{Disciplines}

Accounting | Business Administration, Management, and Operations 


\title{
Are Individuals Entering Self-Employment Overly-Optimistic? An Empirical Test of Plans and Projections on Nascent Entrepreneur Expectations*
}

\author{
Gavin Cassar \\ The Wharton School \\ University of Pennsylvania
}

January 2008

\begin{abstract}
This research examines the rationality of the expectations of nascent entrepreneurs. Consistent with conjectures regarding entry into self-employment, I find substantial over-optimism in nascent entrepreneurs' expectations in that they overestimate the probability that their nascent activity will result in an operating venture. Further, for those ventures that achieve operation, individuals overestimate the expected future sales and employment. To explain cross-sectional variations in over-optimism, I posit that those individuals who adopt an inside view to forecasting, through the use of plans and financial projections, will exhibit greater ex-ante bias in their expectations. Consistent with inside view adoption causing over-optimism in expectations, I find that the preparation of projected financial statements results in more overly-optimistic venture sale forecasts.
\end{abstract}

Keywords: expectations, information acquisition, inside views, forecasting, nascent entrepreneur, over-optimism, planning, rationality.

\footnotetext{
* Correspondence: The Wharton School, University of Pennsylvania, Steinberg Hall-Dietrich Hall (Suite 1300), 3620 Locust Walk, Philadelphia, PA 19104-6365. cassar@wharton.upenn.edu P: (215) 8982023 F: (215) 5732054. The author would like to thank Justin Craig, Gary Dushnitsky, and Dean Shepherd for their insightful comments and the support of Sol C. Snider Entrepreneurial Research Center and Wharton Entrepreneurial Programs. An earlier version of this paper was presented at the 2006 Babson College Entrepreneurship Research Conference. This research would not be possible without the efforts of the Entrepreneurial Research Consortium.
} 


\section{INTRODUCTION}

Expectations of future returns from vocational activity underlie the choice of employment and trigger the decision to start a venture (Cassar, 2006; Shane \& Venkataraman, 2000). Individuals, when choosing to invest their time and capital in nascent entrepreneurial activity, do so with an expectation of success, such as the probability of achieving an operating business. Expectations also underlie the subsequent actions of individuals through the venturing process, such as whether to continue in self-employment or how much additional time and capital to invest (Gimeno, Folta, Cooper, \& Woo, 1997; McCarthy, Schoorman, \& Cooper, 1993). Given the importance of expectations on individual behavior, there are consequences for individuals, their stakeholders, and the economy, to making inaccurate or systematically biased predictions related to entrepreneurial choices.

The rationality of nascent entrepreneurial expectations, that predictions of future outcomes related to venturing activity are made without bias, is often assumed when modeling entry into self-employment and organizational creation (Evans \& Jovanovic, 1989; Evans \& Leighton, 1989). However, researchers acknowledge that individuals are bounded and open to potential influences that may lead them to have biased expectations (Kahneman \& Lovallo, 1993; Kahneman \& Tversky, 1973; Simon 1955). For example, there is substantial evidence that individuals are overly optimistic, in that they overestimate the probability of favorable outcomes

(Weinstein, 1980). ${ }^{1}$ The tendency of nascent and existing entrepreneurs to have over-optimistic expectations may explain why individuals enter and persist in self-employment even in the presence of lower returns from venturing (Camerer \& Lovallo, 1999; Moskowitz \& VissingJorgensen, 2002). While there are conjectures as to the nature of expectations of those entering 
or continuing in self-employment, surprisingly, there is little evidence on the rationality of entrepreneurial expectations. Simply put, there is no research that has investigated how ex-ante expectations of individuals entering self-employment, namely nascent entrepreneurs, map into actual ex-post realizations such as the creation of an operating business, achieved sales growth, or returns from self-employment. Consequently, our understanding of the nature of entrepreneurial expectations and entrepreneurial entry is incomplete.

I address this important gap by longitudinally examining the rationality of the expectations of nascent entrepreneurs, namely those individuals who are currently involved in the process of starting a business, using data from the Panel Study of Entrepreneurial Dynamics (PSED). The distinctive feature of the PSED is that it identifies and surveys nascent entrepreneurs while in the process of starting new ventures, thereby overcoming potential survivorship and recall biases associated with surveying entrepreneurs already in business (Gartner, Shaver, Carter, \& Reynolds, 2004). Further, the PSED longitudinally surveys nascent entrepreneurs throughout the startup process, allowing for the comparison of ex-ante expectations with ex-post realizations, and thereby overcoming the use of perceptual measures of predictions or outcomes.

To understand potential causes for nascent entrepreneurial over-optimism, I examine the influence of information acquisition and use by the entrepreneur on cross-sectional differences in over-optimism. Individuals undertaking nascent venture activity provide a powerful sample for an investigation of over-optimism given the high uncertainty of the forecasting task and the increased likelihood that entrepreneurs will exhibit greater cognitive bias than the general population (Baron, 2004; Busenitz \& Barney, 1997). While, generally, more information is

${ }^{1}$ Consistent with observed over-optimism, some recent theoretical economic models have explicit modeling of optimistic or overconfident individuals into self-employment (Bernardo and Welch 2001; Brocas and 
considered to be beneficial when formulating expectations (Durand, 2003; Forbes, 2005; Simon, Houghton, \& Aquino, 1999), several authors suggest that information acquisition and use may in fact be ineffective in dampening, or may potentially exacerbate, the optimistic tendencies of individuals (Armor \& Taylor, 1997; Kahneman \& Lovallo, 1993; Zacharakis \& Shepherd, 2001). In this paper, I argue that over-optimism in nascent entrepreneurs is exacerbated by the adoption of an "inside view" to forecasting. Individuals form an inside view forecast by focusing on the specifics of the case, the details of the plan that exists, and obstacles to its completion, and by constructing scenarios of future progress (Kahneman \& Lovallo, 1993: 25-26). Researchers have shown that individuals generally adopt an inside view to generate forecasts (Buehler, Griffin, \& Ross, 1994). The inside view is synonymous with the planning fallacy, which focuses the attention of decision makers on the specifics of the problem rather than on the outcomes of similar cases or "base rate" information (Baron, 1998; Kahneman \& Tversky, 1979). Consequently, the planning fallacy, realized through the inside view, is argued to cause the tendency for individuals to hold confident beliefs in the success of their own projects, even when knowing other individuals have failed in similar projects.

I find significant over-optimism in the expectations of nascent entrepreneurs, in that they overestimate the probability that their nascent activities will successfully lead to an operating business. Further, of those nascent entrepreneurs who do achieve an operating venture, I observe that they overestimate both the future sales and number of employees in the first year of operation. These results are consistent with optimistic entry of individuals into self-employment. Cross-sectionally, I find that formal business planning is associated with more optimistic beliefs about future venture operation; however, these beliefs appear justified in that formal business

Carrillo 2004). 
planning also increases the likelihood of venture operation. Consistent with the inside view causing over-optimism in expectations, I find that the preparation of projected financial statements leads to overly-optimistic sales forecasts for the venture. Overall, this study documents that nascent entrepreneurs exhibit substantial over-optimism in their expectations and that over-optimism is influenced by the use of information.

The study findings contribute to theory and practice in several ways. First, it is the first study to provide longitudinal evidence of the rationality of individuals' expectations during the venture evaluation process. As such, it contributes to the literature that seeks to understand the forces that underlie entry and persistence of entrepreneurial behavior, and consequently, organization creation. Second, this study contributes to understanding cross-sectional differences in forecast over-optimism as the first study to investigate how the inside view can affect expectations in a field setting. While the inside view has been conjectured to be associated with over-optimism, there is limited extant theory testing of this within a field sample. The surveying of individuals undertaking start-up activity overcomes concerns from experimental data, which may overstate the role of decision making biases in the field (Camerer \& Lovallo, 1999; Simon \& Houghton, 2003). Third, this study contributes to management practice by providing a link between management practices and observed psychological bias. Understanding what influences forecasting bias is vital for all decision makers, as expectations underlie future actions and behavior. Documenting a relationship between commonly used management practices and optimistic prediction is particularly important, given the fundamental role that financial projections play in allowing decision makers to structure expectations and cope with the future, and because academics and stakeholders generally encourage the use of formal planning and financial projections. The evidence from this study suggests that the same management activities 
that are relied upon and encouraged to be adopted to cope with uncertainty are associated with overly-optimistic expectations.

\section{THEORY DEVELOPMENT AND HYPOTHESES}

\section{Over-Optimism}

While rationality of entrepreneurial expectations is often assumed in economic models of entry into venturing, researchers acknowledge that individuals are bounded and open to potential influences that may lead to them to have biased expectations (Kahneman \& Lovallo, 1993; Kahneman \& Tversky, 1973). There is substantial evidence in many domains that individuals are optimistic (Weinstein, 1980). This evidence shows not only that individuals perceive that favorable events are more likely to happen, but also that favorable events are more likely to happen to them rather than their peers (Taylor \& Brown, 1988). Similarly, individuals generally exhibit overconfidence, in that they overestimate their ability to do well (Larwood \& Whittaker, 1977). Such overconfidence can be in regard to an individual's knowledge, ability to predict the future, or general personal abilities (Hayward, Shepherd \& Griffin 2006: 162; Kruger \& Dunning, 1999; Simon \& Houghton, 2003).

The presence of optimism about exogenous events and excessive self-confidence results in decision makers generally having overly optimistic expectations, in that their expectations of the outcomes regarding their chosen actions exhibit a positive ex-ante bias (Gervais, Heaton \& Odean, 2005; Heaton, 2002; Malmendier \& Tate, 2005a). ${ }^{2}$ In other words, decision makers'

\footnotetext{
${ }^{2}$ Some authors refer to overconfidence to describe the overestimation of expected returns, such as personal wealth, from their decisions (Hayward et al., 2006: 161; Malmendier \& Tate, 2005b: 651). Kahneman \& Tversky (1995: 46) use the term optimistic overconfidence to describe an individual's overestimation of success and their certainty to ensure success. I adopt the term over-optimism from the forecasting literature, which describes the properties of the forecast investigated that is argued to be an outcome of the decision making process (Cassar \& Gibson, 2007; Sedor, 2002).
} 
expectations of future outcomes are more favorable than what eventually occurs. Further, overoptimism tends to be exacerbated when tasks are perceived to be controllable and therefore is likely to be heightened if expectations are based upon planned activity (Weinstein, 1980). In this study's setting, individuals are considered to be overly optimistic when they overestimate the likelihood that their nascent activity will result in an operating venture or when they overestimate the future sales and employment of their new ventures.

However, the presence of over-optimistic beliefs in those that enter nascent entrepreneurship and self-employment does not require optimism, overconfidence, or any presence of psychological bias. Entrepreneurs can hold over-optimistic beliefs simply as a consequence of acting rationally on noisy yet unbiased signals of returns from vocational activity (Van den Steen, 2004). Whereby, those individuals who act on favorable signals from venturing are more likely to have observed signals with optimistic errors (Brown, 1974; Harrison \& March, 1984). Therefore, simple self-selection, based on rational choices can result in over-optimism in those who choose to undertake nascent activity and become entrepreneurs. Given its definition and measurement, over-optimism is observed in this study regardless if it is a consequence of cognitive bias or hubris, of simple self-selection, or of a combination of these effects.

While there is no evidence in the extant literature of the rationality of nascent entrepreneurial expectations, Cooper, Woo, and Dunkelberg (1988) observed that existing entrepreneurs reported the odds of their business "succeeding" to be significantly higher than historically observed and substantially better than the odds of success for other similar businesses. They concluded that the observed differences in expectations was likely caused by ex-post decision bolstering, in that once the entry into self-employment had been made, entrepreneurs were likely to justify this choice by believing it would lead to success. In this study 
setting, ex-post decision bolstering can not be a cause of optimism, as the expectations observed are elicited before the venture is operational.

Hypothesis 1. Nascent entrepreneurial expectations are overly-optimistic.

\section{Plans and Projections}

I argue that over-optimistic forecasts of nascent entrepreneurs' results from the inside view whereby predictions are anchored on plans in which individuals have a vested interest. Individuals generate an inside view forecast by focusing on the case at hand, considering the plan and obstacles to its completion, and constructing scenarios of future progress (Kahneman \& Lovallo, 1993: 25). The inside view, which is synonymous with the planning fallacy, draws on knowledge of the specifics of the case, details of the plan, and ideas about how likely obstacles might be overcome. The inside view represents an individual's attempt to come to grips with the complexities of the unique characteristics and circumstances of the task or project. In contrast, an outside view is statistical and comparative in nature and does not involve any attempt to divine the future at any level of detail (Kahneman \& Lovallo, 1993: 25).

Consistent with an inside view approach, evidence from experimental research suggests that people typically make forecasts by constructing a mental scenario of how the project is likely to develop (Buehler et al., 1994). Scenarios can be described as representations of temporally ordered sequences of events glued together by causal relationships (Griffin, Dunning, \& Ross, 1990; Johnson \& Sherman, 1990). The process of scenario formulation allows the decision maker to evaluate a given problem in a step-by-step manner by analyzing the outcome of a series of causal events (Hastie \& Dawes, 2001). Experimental research has also shown that when individuals are provided with reasons or scenarios for why an outcome will be achieved, 
their expectation of that outcome occurring increases (Hoch, 1984; Levi \& Pryor, 1987). Buehler, Griffin, \& MacDonald (1997) found that when participants were given incentives to complete a task, they exhibited greater optimistic bias. Further analysis revealed that the incentives focused participants more narrowly on their plans, consistent with the inside view. Consequently, the inside view tends to exacerbate tendencies of optimism and overconfidence that are observed in individuals' decision making and formulation of expectations.

The use of plans and projections by entrepreneurs is associated with scenario representation. For example, a formal business plan specifies the goals of the firm, and how the firm will achieve these goals through strategic to operational detail. Similarly, financial projections provide a monetary representation of the goals and expected performance of the firm. Business plans and financial projections emphasize the interrelationship between and among various activities and actions of the firm. For example, strategic goals lead to operational goals, which lead to specific tasks to enable goal attainment. Financial projections are a function of strategies and planned behavior. Further, the relevance of outside sources can be masked by detailed acquaintance with the specific case or by intense involvement in it (Kahneman \& Tversky, 1979). As more information is provided to the decision maker, such as through formal documents detailing scenarios of goal achievement, the individual's propensity to employ an inside approach should increase, reducing the consideration given to outside sources of information. Consequently, the development of business plans or financial projections should encourage or be reflective of an inside approach to the formulation of expectations.

While entrepreneurs can make plans or set financial targets without formally developing business plans or financial projections, it is undertaking these management activities that encourage reflection on the implementation of one's actions, thereby making people more 
confident in the success of the plan or the probability of achieving the targets specified (Armor \& Taylor, 1998; Taylor \& Gollwitzer, 1995). Social psychologists suggest that people become more confident in their beliefs when they generate explanations for their choices and beliefs (Heath \& Gonzalez, 1995). Further, the inside view may exacerbate other biases in decisionmaking that can contribute to over-optimism. For example, when individuals focus on their own capabilities and actions, they may neglect the abilities and potential actions of competitors (Lovallo and Kahneman, 2003). Additionally, individuals may anchor on the positive goals formulated in plans and financial projections, such as estimated revenue, and not place enough weight to new information, such as recent sales (Tversky and Kahneman, 1974). Consequently, the development or use of plans and scenarios by individuals with a vested interest in these planned behaviors is more likely to exacerbate tendencies to formulate over-optimistic expectations.

An important aspect of the arguments relating the inside view to forecasting bias is the context and setting of the forecast. As with decision making generally, the presence of nonrational expectations is more likely in situations of high uncertainty or complexity (Kahneman,

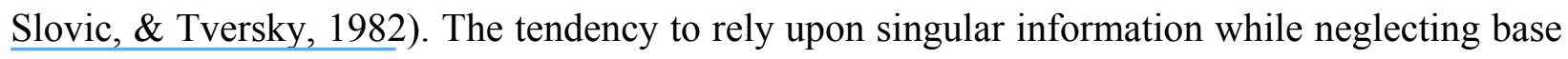
rate or distributional information is enhanced by the perceived uniqueness of the problem (Kahneman \& Tversky, 1979). Consequently, the inside view arguments do not pertain to decisions that are routinely repeated, with the critical question being whether a particular problem or forecast is treated as unique, or as a problem similar to many others (Kahneman \& Lovallo, 1993: 25). Grossly optimistic forecasts may be especially likely if the forecasts relate to a new technology or new type of project or otherwise places the forecaster in an unfamiliar or dynamic setting (Hayward et al., 2006: 164). In contrast, opportunities for learning and for 
statistical aggregation exist when closely related problems are frequently encountered (Kahneman \& Lovallo, 1993: 18). All of this suggests that studying nascent entrepreneurs during the startup stage provides a powerful setting to investigate the influence of the inside view on forecasting biases.

Hypothesis 2. Nascent entrepreneurs who adopt plans and projections have expectations that are more overly-optimistic.

\section{METHOD}

\section{Sample}

I used the Panel Study of Entrepreneurial Dynamics (PSED) to investigate the rationality of entrepreneurs' expectations. ${ }^{3}$ The distinctive feature of the PSED is that it identifies and surveys nascent entrepreneurs in the process of starting new ventures, thereby overcoming potential survivorship and recall biases, such as hindsight bias, self-justification bias, and attribution bias, associated with surveying entrepreneurs already in business (Conway \& Ross, 1984; Golden, 1992; Hawkins \& Hastie, 1990). The PSED screened 64,622 individuals from the U.S. mainland, aged 18 or older, who were randomly selected using random-digit-dial sampling (Gartner et al., 2004). The screening phone interview asked if the respondent, alone or with others, was currently trying to start a new business. The respondents who answered yes were further asked if: 1) they expected to have at least some ownership in the new firm; and 2) they actively tried to start the new firm in the past 12 months. Those 3,592 respondents who answered yes to both the above questions were considered eligible for the nascent entrepreneur interview.

\footnotetext{
3 Research using data, questions, or research designs developed from the PSED has been published in numerous mainstream management and entrepreneurship based journals including: Entrepreneurship Theory and Practice, Journal of Business Venturing, Journal of Management, Journal of Small Business Management, Small Business Economics, Strategic Management Journal, and Management Science.
} 
Of those 3,592 respondents, 3,158 (87 percent) volunteered to participate in future interviews. A random sub-sample of 1,164 respondents was selected, contacted, and asked a further screening question to ensure that their current activity was considered a nascent effort rather than an infant business. Specifically, they were asked: "Has the start-up had a positive monthly cash flow that covers expenses and the owner-manager salaries for more than three months?" All respondents who reported that their nascent venturing activity achieved positive cash flows for more than three months at the time of the phone survey were removed, resulting in 830 nascent entrepreneurs who were subsequently phone interviewed in the first wave of the survey. ${ }^{4}$

Nascent entrepreneurs chosen for this study were chosen as those attempting to start a new business, but not on behalf of an employer. These two criteria ensure that the expectations and characteristics observed relate specifically to the respondent rather than occur as a consequence of undertaking entrepreneurial activities on another person's behalf. ${ }^{5}$ Further, I exclude nascent activity related to the purchase or take-over of existing businesses and franchise or multi-level marketing initiatives. Given the focus of the research on expectations before business operation, I remove all respondents who reported that their nascent activity had achieved positive monthly cash flow at the time of the first phone interview. These additional criteria reduced the sample size to 592 respondents. All expectations used in this study were solicited from this nascent entrepreneur sample during the remainder of the first phone interview.

4 The rationale for adopting this definition was to be consistent with other PSED research that has investigated nascent venture activity. Under the PSED sampling, the achievement of positive monthly cash flows for more than three months was considered an infant business and not a start-up effort (Gartner et al. 2004). To examine the concern that including ventures that were generating revenues in the sample was spuriously affecting the findings I removed all start-up activity that had any revenues at the time of the first survey. The findings for the remaining sub-sample were the same as the full sample.

${ }^{5}$ A single respondent approach was used as the research focus is on expectations of individuals undertaking nascent activity. Given nascent activity that involves a startup team is comprised of individuals, each with an expectation of success that underlies their decision to be involved and remain involved in the nascent activity, the study findings are applicable to both individual and team based nascent activity. In 36 percent of the nascent ventures studied, the entire startup team consisted of a single founder. 
Finally, I limit the sample to the 386 respondents who reported at least one expectation and subsequently reported the associated ex-post realization.

An examination of potential sample bias between those who responded in future phone interviews and those who did not, revealed no statistically significant differences with regard to respondent gender, age, formal business planning, financial projections, expectations of venture operation, or first-year venture sales and employees.

\section{Variables}

Bias. Three expectations of the nascent entrepreneur were empirically examined in this study, namely: 1) likelihood of start-up becoming an operating business; 2) future sales in the first full year of operation; and 3) number of future employees, excluding owners, at the end of first full year of operation. To examine the expectation of the start-up becoming an operational business, the respondents were asked: "On a scale of zero to one hundred, what is the likelihood that this business will be operating five years from now, regardless of who owns and operates the firm?" The likelihood obtained is referred to as the nascent entrepreneurs' expectation of operation. For expectations of future sales, nascent entrepreneurs were asked: "What would you expect the total sales, revenues, or fees to be in the first full year of operation?" While expectations related to fifth-year sales were also elicited, given the temporal period of the longitudinal survey, information regarding actual sales related to the fifth-year operations was not obtained by the PSED. For employment expectations, the entrepreneurs were asked: "By the end of the first full year of operation, about how many full-time employees, not counting owners, do you expect to be working for pay at this new business?"

${ }^{6}$ In addition to this measure, a further employment expectation measure was calculated to incorporate expectations of part-time employees. This alternative expectation measure is the sum of expected full time employment plus half the expected part time employment. The results are invariant to the alternative expectation measure and consequently are not reported. 
Entrepreneurs self-reported whether the start-up was an operating business in follow up phone interviews. These interviews were conducted in three waves at a mean (median) 14 (13), 33 (32), and 56 (56) months following the initial screening interview. Respondents were asked to classify the current status of the start-up effort as a(n): 1) operating business; 2) active start-up; 3) inactive start-up; and 4) no longer worked on by anyone. All those who reported the existence of an operating business, and who did not abandon the operating business at a future date, were coded as operating. All those who reported that the business was no longer worked on by anyone were coded as not operational unless other team members had successfully started the venture. Those respondents reporting active and inactive start-up activity more than five years from the original phone interview were classified as not operational. All remaining start-ups that were not operational or abandoned, and for which a phone interview was not undertaken at least 60 months after the original phone interview, were classified as missing. Table 1 provides a descriptive summary of the 386 respondents' status obtained from the follow-up phone interviews. ${ }^{7}$ The degree of over-optimism in venture operation was determined as the difference between the nascent entrepreneur's likelihood of venture operation and an indicator variable (Status) that equals "1" if the venture is operational and " 0 " otherwise, as follows:

Operational Over-Optimism $=$ Expectation of Operation - Status

Insert Table 1 about here

Sales and employment information were also obtained in the three follow-up phone interviews. Given that sales and employment expectations were framed on the assumption that

${ }^{7}$ The findings are quantitatively similar if: 1) the 20 ventures started by other team members firms are excluded from the sample; 2) the operating ventures classification included the 29 ventures that operated and subsequently reported in future phone interviews that the business was shut down; and/or 3) a further 53 ventures 
the venture was operational, these analyses are only undertaken for those start-ups that became operating businesses. For sales, entrepreneurs who were involved in a start-up that had completed its first full year of operation were asked what sales or revenue was achieved in the first full year of operation. I conducted validity checks on the timing of the ventures' launch and the timing of the responses and removed cases where the responses did not represent first-year operations. ${ }^{8}$ For numbers of employees, entrepreneurs who were involved in a start-up that employed a non-owner employee were asked to provide the number of non-owner employees hired in full-time and part-time capacities. The degree of over-optimism, for sales and employment, was determined as a function of ex-ante expectations (F) and actual realizations (A), as follows:

(Sales or Employment) Over-Optimism $=$ F - A / $(\mathrm{F}+\mathrm{A})$

The use of deflators reduces heterogeneity in the sales and employment over-optimism measures obtained. ${ }^{9}$ Importantly, all measures of bias in this study, through the utilization of exante expectations in comparison with ex-post realizations, overcome the use of perceptual measures of expectations, such as "success," using specific traits or characteristics to proxy for optimism, or inferring optimism using observed optimistic biases in other domains (Cooper et al., 1988; Lowe \& Ziedonis, 2006; Puri \& Robinson, 2005). Further, the confidential nature of the PSED removes gaming concerns associated with forecasts that are observable to venture

that were active or inactive after 48 months but not phone interviewed afterwards were classified as not operational instead of missing.

${ }^{8}$ These validity checks included removing ventures that were not operational for more than one year and removing responses in follow-up phone interviews that related to the second-year's, rather than first-year's, operations.

${ }^{9}$ Other approaches to reduce heterogeneity in the forecast error included using just the ex-ante expectation or actual realization as the deflator and trimming, winsorizing, or log transforming the forecast error. The deflator utilized was chosen as the skewness and kurtosis of this measure was substantially closer to zero, which is critical for parametric-based testing. Notably, the study findings are invariant to alternative forecast error specifications discussed above. 
stakeholders. For example, without confidentiality, entrepreneurs may upwardly bias observable forecasts or actual realizations to present themselves or the venture in a more favorable light to stakeholders or downwardly bias actual realizations to lower tax or regulatory costs.

Entrepreneur Behavior. The behaviors empirically examined in this study are: 1) formal business planning; and 2) financial projections. A business plan was defined as something that "usually outlines the markets to be served, the products or services to be provided, the resources required - including money - and the expected growth and profit for the new business." Formal business planning was determined to be present when nascent entrepreneurs responded that they had a business plan and that the current form of the plan was "formally prepared." Those responding in the affirmative were coded " 1 " and " 0 " otherwise. ${ }^{10}$ The undertaking of financial projections was represented by a dichotomous variable ("1" yes, " 0 " otherwise) based on the question: "Have projected financial statements, such as income and cash flow statements or break-even analysis, been developed?"11

Controls. The characteristics of the entrepreneur may be associated with the overoptimism of their forecasts. For example, research has shown that males are generally more optimistic and more likely to overestimate future performance than females (Henry, 1994; Puri \& Robsinon, 2005). Further, cognitive ability, knowledge, or experience of the forecasting task

${ }^{10}$ Alternative definitions, such as defining business planning to represent all business plans regardless of whether the plan was "informally written" or "formally prepared", or adopting a hierarchical based planning measure, were not utilized as the formal nature of planning is more likely to induce behavior consistent with the inside view (Buehler et al., 1994; Kahneman \& Lovallo, 1993). Further, the use of dichotomous predictor variables or manipulations is consistent with experimental research in expectation formation and empirical research on business planning (Hoch, 1984; Levi \& Pryor, 1984, Sedor, 2002; Delmar \& Shane, 2003; Shane \& Delmar, 2004).

${ }^{11}$ Another entrepreneurial behaviour that may be associated with over-optimism is the obtaining of market information by the venture team. Specifically, the PSED asked "Has an effort been made to define the market opportunities by talking with potential customers or getting information about the competition?" All the results were replicated including this independent variable, which was coded as " 1 " for yes and "0" otherwise. In unreported results, no support was found for an association between market information and over-optimism. However, very limited variation in this market information variable in the sample may also have resulted in a failure to find an association with over-optimism. 
should reduce the error or bias in predicting future outcomes (Forbes, 2005). I control for three characteristics based on the demographics of the nascent entrepreneur, namely: 1) education; 2) gender; and 3) industry experience. Education was operationalized by a variable denoting the highest level of educational attainment of the respondent, being: 1) up to high school; 2) technical/vocational; 3) some college including associates degrees; 4) bachelors degree; and 5) post college. Gender was a dichotomous variable, coded as "1" for female and " 0 " for male. Industry experience is the number of years the respondent has work in the industry of the nascent venture.

Several venture organizing activities were utilized to control for the stage of development of the nascent venture (Shane \& Delmar, 2004). Venture organizing activities may be associated with a nascent entrepreneur's expectations, as the more activities undertaken, the greater the knowledge of the venture and its viability. Further, as more activities are undertaken, the greater influence of selection bias in the remaining set of nascent entrepreneurs, as those nascent entrepreneurs that obtain confirming (disconfirming) information about the venture's viability or success will be more likely to continue (disband) the nascent activity. Product development was determined from the response to: "at what stage of development is the product or service this (start-up/new firm) will be selling: 0) still in the idea stage or no work has been done on a product or service; 1) a model or procedure is being developed; 2) a prototype or procedure has been tested with customers; or 3) completed and ready for sale or delivery?". This product development variable was deflated by three to provide a variable similar to the other independent variables which were bounded between 0 and $1 .{ }^{12}$ The extent to which the startup had begun

\footnotetext{
${ }^{12}$ The decision to specify product development as an ordinal variable, rather than a series of categorical variables, was to constrain a monotone relationship between the extent of venture organizing activities and the dependent variables. In unreported results, the empirical findings were found to be quantitatively similar when product development was specified as a series of categorical variables.
} 
marketing and promotion activities was obtained from the dichotomous response to: "Have marketing or promotional efforts been started (for the product or service this (startup/new firm) will be selling)?" A yes response was coded "1" and " 0 " otherwise. The extent to which the startup had begun to obtain raw inputs was solicited from: "Have any raw materials, inventory, supplies, or components for the new (start-up/business) been purchased?" A yes response was coded " 1 " and " 0 " otherwise. The extent to which the startup had begun to obtain capital inputs was solicited from: "Have any major items (\$1000 or more) like equipment, facilities, or property been purchased, leased, or rented for the new (start-up/business)?" Again, a yes response was coded " 1 " and " 0 " otherwise. In addition, a variable representing whether the startup had received revenue was solicited from: "Has the new business received any money, income, or fees from the sale of goods or services?" Those that had received revenue were coded "1", otherwise " $0 "$ ".

\section{RESULTS}

\section{Descriptive Statistics}

Table 2 presents the descriptive statistics and correlations of the study variables. Examining the descriptive statistics reveals substantial over-optimism in nascent entrepreneurs. First, significant over-optimism is observed in the nascent entrepreneurs' expectations of venture operation. At the mean (median), nascent entrepreneurs believe there is an 81.0 percent (90 percent) chance that their nascent activity will result in an operating venture; however, only 47.8 percent of ventures actually achieve operation, resulting in a mean bias in the expectations of venture operation of 33.2 percent $(t=12.33, p<.0001) .{ }^{1314}$ Second, of those that achieved

\footnotetext{
${ }^{13}$ While substantial optimistic bias was observed, the expectation of operation and the eventual status of the venture was significantly positively correlated in the sample $(\rho=0.14, p<.01)$. Therefore, those individuals that
} 
operation and had available first-year sales information, significant overestimation of projected sales is observed, with 62 percent overestimating first-year sales as opposed to 34 percent underestimating sales, resulting in a mean (median) sales over-optimism of $0.17(0.25)$. Third, employment expectations were also overly optimistic, with 46 percent overestimating employment after one year of operations as opposed to 28 percent underestimating employment. Overall, the evidence presented is consistent with nascent entrepreneurs being overly-optimistic, and therefore supports hypothesis one.

Insert Table 2 about here

\section{Cross-Sectional Differences in Optimistic Bias}

Table 3 reports a series of regressions reporting cross-sectional differences in expectations of venture operation and operating optimism. Given the bounds on the dependent variables, the assumptions that underlie the error distributions of ordinary least squares are not appropriate: consequently, I use generalized method of moments (GMM). ${ }^{15}$ For descriptive purposes, the first three columns report the coefficients from models predicting the expectations of operation by nascent entrepreneurs. These regressions are analogous to empirical research that has examined entrepreneurial expectations without considering ex-post outcomes. Reporting both the nascent entrepreneurs' likelihood of success and the bias associated with their expectations allows comparison between those behaviors or attributes that are associated with

predicted their nascent activity would become an operating venture were more likely to become operating ventures, suggesting that respondents, while biased, were careful when providing operational expectations for their startups.

${ }^{14}$ Significant over-optimistic expectations $(p<0.05)$ are observed for all major SIC divisions with greater than 15 observations.

${ }^{15}$ Regression techniques that incorporate censored dependent variables, such as tobit regression, are not appropriate, as the assumptions of self-selection and censorship that underlie these models are not present for the dependent variables investigated in this study (Maddala, 1993; Wooldridge, 2003: 553). 
positive expectations and those that are associated with overly-optimistic expectations. Requiring non-missing values for all independent variables reduced the analysis to 368 observations. The coefficient on formal business planning is $8.42(p<.001)$, suggesting that undertaking this activity significantly increases the nascent entrepreneur's expectation of operation by 8.42 percent. However, whether formal planning is associated with optimism is determinant on how planning is associated with subsequent venture operation.

Examining cross-sectional variations in operational over-optimism reveals that the coefficient on formal business planning for observed over-optimism is consistently negative and insignificant. Therefore, while formal business plan preparation increases the expectation that the venturing activity will lead to an operating venture, such preparation is not associated with overly optimistic expectations, as planning is also positively associated with the likelihood that the nascent activity will become an operating venture. The coefficients on capital inputs and money received is negative, suggesting that individuals whose nascent activities have purchased significant capital inputs for the venture or who have received money have a lower bias in their expectations of venture operation than those who do not. However, while this bias is lower, individuals that have undertaken these activities still appear to exhibit optimism. Overall, the evidence presented for operational over-optimism does not support hypothesis two.

Insert Table 3 about here

Table 4 presents the GMM regression analysis for those ventures that achieved operation for one year or more. Given the relatively small number of observations available for both sales 
and employment, formal business planning and financial projections are included in separate models to avoid harmful multicollinearity (Kennedy, 2003) ${ }^{16}$

Model 1 shows that formal business planning is not associated with sales optimism. However, in model 2, it is observed that the preparation of projected financial statements leads to more optimistic forecasts in regard to venture sales $(p<.01)$. This result is consistent with the inside view causing over-optimism in expectations. In particular, the undertaking of financial projections encourages the nascent entrepreneur to adopt an inside view in regard to the financial performance of the venture, resulting in overly-optimistic financial expectations. This result is consistent with hypothesis two. Further, the above association is invariant to the inclusion of venture organizing activities in the full model presented in column three. The results from model 3 also show that nascent entrepreneurs whose ventures have received money from the sales of goods or services have significantly less over-optimism in their sales expectations. This demonstrates the benefit of actually making sales in improving the rationality of financial sales expectations. $^{17}$

Interestingly, for employment over-optimism, the relationship between optimism and financial projections is no longer found, with the coefficients on models 5 and 6 actually being negative and insignificant. An explanation for the difference between sales and employment is

${ }^{16}$ The condition index is advocated to be the best indicator of multicollinearity and is calculated as the square root of the ratio of the largest to the smallest characteristic root of $\boldsymbol{X}^{\prime} \boldsymbol{X}$ (Belsley 1991; Kennedy 2003). The condition index on the full models presented in Table 4 with the inclusion of both formal business planning and financial projections was above 25, which is suggestive of harmful collinearity (Belsley, Kuh, \& Welsch, 1980). An explanation for the greater collinearity observed in these models, beyond the reduction in sample size, is the stronger correlation between formal business planning and financial projections for the sub-sample of ventures that achieved operation for one year or more.

${ }^{17}$ To investigate the possibility that reported over-optimism in sales was driven by pressure placed on entrepreneurs by investors to facilitate investment both the sales expectations and over-optimism of sales were compared for those who had asked financial institutions and other people for funding and those who have not. There were no significant differences between these two groups $(t=1.02, p=0.31)$ and $(t=0.32, p=0.75)$, suggesting that this concern was not driving the presence of over-optimism. It should also be noted that given the survey is confidential there should be no incentive on the entrepreneur to artificially inflate their reported expectation to satisfy outside stakeholders. 
that financial projections are the monetary representation of the financial outcomes of intended behavior. Therefore, the nexus between sales and financial outcomes is more direct than the nexus between employment and financial outcomes. For example, additional employment may be associated with increased scale, which may represent larger financial returns, but it may also bring increased costs, which are associated with lower financial returns to the entrepreneur. In comparison, sales are specifically modeled in financial projections, and greater sales are directly associated with positive outcomes for the entrepreneur. Therefore, even though both sales and employment expectations were highly positively correlated in the sample $(\rho=.49, p<.001)$, the undertaking of financial projections has different implications for the beliefs of nascent entrepreneurs in regard to sales and employment.

Insert Table 4 about here

\section{DISCUSSION}

\section{Implications for Theory and Practice}

The study findings are of interest for several reasons. First, it is the first study to provide longitudinal evidence of the rationality of individuals' expectations during the venture evaluation process. The advantage of the longitudinal approach is that it elicits expectations of nascent entrepreneurs and compares them to observed outcomes, thereby overcoming methodological concerns of extant research evaluating the expectations of decision makers. Extant research has demonstrated that individuals who are optimistic about their life expectancy or those that have higher self-efficacy are more likely to be an entrepreneur than in career employment (Puri \& Robinson, 2005; Zhao, Seibert, \& Hills, 2005). Similarly, extant research has found that individuals who are overconfident in the certainty of their knowledge, in that they overestimate 
the correctness or precision of their beliefs in answering challenging questions or predicting the future, are more likely to be entrepreneurs and more likely to undertake product introductions that are pioneering or risky (Busenitz \& Barney, 1997; Forbes, 2005; Simon \& Houghton, 2003). However, these research approaches cannot answer whether individuals entering venturing are overly-optimistic in regard to the venturing activities they undertake, as this can only be achieved through comparing ex-ante expectations with ex-post outcomes. By providing specific evidence demonstrating that individuals entering venturing overestimate the benefits from undertaking nascent activity and subsequent entrepreneurship, this research contributes to the literature that seeks understanding of the forces that underlie entry into and persistence of entrepreneurial behavior.

Cooper et al. (1988) observed that individuals who recently became entrepreneurs reported their odds of business success to be substantially higher than historically observed and greater than the odds of success for other similar businesses. Given their research design, the authors posited that these beliefs were caused by post-decisional bolstering. In the current study setting, ex-post decision bolstering cannot be a cause of optimism, as the expectations observed are elicited before the venture is operational. The evidence from this study cannot confirm or reject that bias related to ex-post decision bolstering is present in entrepreneurs; however, it does suggest that the presence of optimistic beliefs in entrepreneurs is not contingent on the presence of ex-post decision bolstering.

Second, this study contributes to theory by being the first study to empirically investigate how the inside view can affect expectations in a field setting. While there is evidence of the presence of such views in forecasting behavior within a population generally, little research has investigated cross-sectional differences of inside view adoption and forecasting biases within 
sample (Buehler et al., 1994). For example, while researchers conjecture that individuals are generally too optimistic, it is unclear whether those who adopt a more inside view to forecasting are more likely to have forecasting biases. Consequently, we have little understanding of crosssectional differences in forecasting rationality for individuals in similar settings. Further, there is a lack of understanding about how the inside view influences expectations and beliefs in field settings, with the limited evidence related to the inside view based on experimental settings. By using a field design, I address concerns that experimental designs may overstate the presence of bias in decision making, given their reliance on salient signals, lack of meaningful incentives, or insufficient task orientation (Schwarz, 1994). This study demonstrates that differences in management behaviors consistent with the inside view appear to be an economically significant influence on expectation formation and contribute to understanding cross-sectional differences in forecast optimism in the field.

Further, distinguishing between different types of expectations revealed that financial projections, while being associated with overly-optimistic sales expectations, were not associated with overly-optimistic employment expectations. Such a finding is analogous with the compatibility principle, which has been observed in experimental settings, whereby the weight of any input component is enhanced by its compatibility with the output. For example, when subjects were asked to provide a numerical output, such as a dollar amount, numerical data had a greater impact on their response than other data that was less compatible in content, scale, or display (Tversky, Sattath, \& Slovic, 1988). As financial projections are the monetary representation of the outcomes of intended behavior, they should be more likely to encourage reflection on the causal events that lead to the financial outcomes. Further, employment outcomes are more ambiguous in regard to the financial performance of a venture than are sales 
outcomes. For example, greater sales and growth may lead to greater need for the venture to employ more people; however, more employees also represent greater costs, thereby reducing the financial returns from the venture. In other words, the undertaking of financial projections is associated with overly-optimistic expectations for financial outcomes, but not necessarily for other outcomes. The varying implications for the expectations of decision makers from different management behaviors highlights the importance of the context of the inside view and the types of plans and projections used in shaping expectations.

Third, the study provides empirical evidence for cross-sectional differences in forecast optimism distinguishing between ex-ante beliefs and ex-post outcomes. In particular, the evidence suggests that formal business planning by the nascent entrepreneur, while being associated with a greater likelihood that their nascent activity would lead to an operating venture, is not associated with overly-optimistic beliefs. The explanation for this finding is that formal business planning facilitates venture formation, increasing the likelihood of entrepreneurs completing the tasks required to progress their nascent activity into an operating business. The specific mechanism that planning facilitates organizational creation may be through focusing goal attainment and allowing individuals to make faster decisions than with trail-and-error learning (Delmar and Shane, 2003). Alternatively, regardless of the specific strategies and goals set, the presence of a formal plan may stimulate structure to animate and orientate individuals act with more intensity (Weick, 1995). This finding also demonstrates the importance of longitudinal designs to distinguish between those behaviors or attributes that are associated with positive expectations from those that are associated with unjustified or overly-optimistic expectations.

More generally, the study findings are of interest to decision makers. While research has examined the forecast accuracy of decision makers, there is limited understanding of how 
particular behaviors influence forecasting bias (Durand, 2003). For example, there is little evidence on whether commonly used management practices moderate the level of optimistic or extreme prediction. Consequently, this study provides an important link between observed psychological bias and management practices, namely financial projections. This documented relationship is particularly important, given the fundamental role that financial projections play in allowing decision makers to structure expectations and cope with the future. The evidence from this study suggests that the same management activities that entrepreneurs rely on to cope with uncertainty appear to be causing individuals to hold optimistic expectations. Acknowledging how management practices bias expectations may allow decision makers to use organizational or decision-making controls to reduce this influence. For example, generating reasons why the planned outcome may not be achieved or consciously relating past experiences to the forecasting task at hand are approaches individuals can take to reduce overly-optimistic or overconfident forecasts (Buehler et al., 1994; Koriat, Lichtenstein, \& Fischhoff, 1980). In a group setting, the use of conflict-based approaches, whereby members critique proposals and make counter arguments may result in more realistic expectations (Schweiger, Sandberg, \& Ragan, 1986).

Another decision-making de-biasing technique is adoption of the outside view. Through incorporating relevant information that decision-makers may otherwise neglect, the outside view should avoid the over-optimistic tendencies from scenario thinking (Kahneman \& Lovallo, 1993; Kahneman \& Tversky, 1979). Specifically, with knowledge of the outcomes from similar previous endeavors, decision-makers' expectations can be formed through evaluation of how their present endeavor compares to previous endeavors. Within this evaluation, decision-makers should also de-bias their expectations by factoring out historically observed forecasting errors 
made by similar endeavors and control for over-optimistic tendencies when comparing their endeavor's future performance to previous similar endeavors (Flyvbjerg, 2004; Lovallo \& Kahneman, 2003). Therefore, this study also has implications for nascent entrepreneurs, as the findings demonstrate a general forecasting bias in those entering venturing. An awareness of the biased forecasting tendencies of those in similar decision-making settings may allow individuals considering future entrepreneurial activity to incorporate knowledge of bias into future expectations. However, the benefits of awareness may be tempered by the tendency for decision makers to ignore such warnings depending on the perceived uniqueness of their venture opportunity.

\section{Limitations and Future Research}

The study's focus on individuals undertaking nascent venture activity is a powerful setting in which the inside view tendencies are heightened, given the uniqueness of the forecasting task and the vested interest of the forecaster. Future research should investigate the extent to which inside view adoption, and the use of management practices associated with the inside view, affects the expectations of decision makers in settings beyond nascent venturing activity. For example, in an organizational setting, the use of groups and the extent to which organizational controls are in place to reduce optimistic bias or provide forecasting discipline may reduce or exacerbate decision makers' optimistic bias on the expectations of decision makers (McNamara \& Bromiley, 1997). Variations in the nature of the forecasting task, such as the degree to which a forecast is unique or recurrent, and the degree to which the forecaster has a vested interest in the prediction or outcome may all influence both forecasting bias and the influence of management behavior on forecasting bias. Such empirical investigations of the 
inside view may provide insight by testing the bounds of theory to which the inside view is posited to influence expectations or exacerbate boldness in forecasting.

Many financial intermediaries require ventures to submit financial projections in order to be eligible for financing. Such behavior is considered good business practice and not only provides potential financiers with information concerning the investment project, but also signals the competence and quality of the management team. The empirical findings show that the act of preparing financial statements is associated with more optimistically biased sales projections. Clearly, financial intermediaries and other stakeholders can undo any bias by the preparers through due diligence or superior knowledge (Cable \& Shane, 1997). To what extent outside stakeholders are susceptible to potential biases in decision making is an interesting question for future research. For example, how does financier confidence and optimism change as a result of an entrepreneur's submission of formal business plans or financial projections, or direct discussions with entrepreneurs? Experimental evidence from other groups, such as venture capitalists and financial analysts, suggests that they too are susceptible to simple manipulations in the format of information, consistent with scenario thinking (Sedor, 2002; Zacharakis \& Shepherd, 2001).

While the findings presented here demonstrate that nascent entrepreneurs are overly optimistic, it is important to recognize that the population investigated in this study is distinct from those considered to be existing owners and managers of firms. Extant evidence regarding the presence of over-optimistic beliefs in entrepreneurs and managers in established firms, which has utilized a longitudinal design comparing ex-ante expectations with ex-post realizations, has been limited and inconclusive (Ashworth, Johnson, \& Conway, 1998; Cassar \& Gibson, 2007). Differences between nascent entrepreneurs and other decision makers may be a consequence of 
differences in ability, forecasting process, and variations in the nature of forecasting undertaken. The extent to which entrepreneurs learn about their venture opportunity during the operation of the firm through feedback and the learning achieved from venturing experience that may improve their evaluations of expectations related to future nascent activity could be determined with longer time-series data beyond the scope of the PSED. These important questions are left to future research.

The empirical analyses in regard to over-optimism in one-year sales and employment expectations were achieved with a relatively small sample, primarily because only those nascent entrepreneurs that subsequently achieved an operating venture, were interviewed, and completed the realizations after one year's operation were available for comparison. The attrition resulting from the low proportion of nascent ventures that become operating ventures and the longitudinal nature of data collection can be addressed in future research by starting with a greater number of respondents in the first stage of data collection. Importantly, even given the relatively small sample, the association between financial projections and over-optimistic financial expectations was observed.

\section{Conclusion}

This research examines the rationality of the expectations of nascent entrepreneurs during new venture start-up. Consistent with conjectures regarding entrepreneur entry, this study finds substantial over-optimism in expectations, in that nascent entrepreneurs overestimate the probability of their nascent activity becoming an operating venture. Further, nascent entrepreneurs overestimate future one-year sales and employment of the venture, suggesting that they are overly-optimistic both in regard to the success of their venturing activity and the actual performance of their operating ventures. 
Additionally, this study demonstrates important linkages between the psychological biases present in nascent entrepreneurs' forecasts and their use of typical management activities. The adoption of plans and scenarios, in particular financial projections, significantly exacerbates tendencies for individuals to make financial forecasts that are too optimistic. This suggests that the same management activities that are advocated by academics and adopted by individuals to cope with the future are associated with nascent entrepreneurs having irrational expectations. Given the importance of organizational creation and venture growth, and the expectations that underlie them, the findings from this study have important implications for both theory and practice. 


\section{REFERENCES}

Armor, D. A., \& Taylor, S. E. 1998. Situated optimism: Specific outcome expectancies and selfregulation. In M. P. Zanna (Ed.), Advances in experimental social psychology, vol. 30: 309-379. New York: Academic Press.

Ashworth, J., Johnson, P., \& Conway, C. 1998. How good are small firms at predicting employment? Small Business Economics, 10: 379-387.

Baron, R. A. 1998. Cognitive mechanisms in entrepreneurship: Why and when entrepreneurs think differently than other people. Journal of Business Venturing, 13: 275-294.

Baron, R. A. 2004. The cognitive perspective: A valuable tool for answering entrepreneurship's basic "why" questions. Journal of Business Venturing, 19: 221-239.

Belsley, D. A. 1991. Conditioning diagnostics. New York: John Wiley.

Belsley, D. A., Kuh, E. \& Welsch, R. E. 1980. Regression diagnostics: Identifying influential data and sources of collinearity. New York: John Wiley.

Bernardo, A. E., \& Welch, I. 2001. On the evolution of overconfidence and entrepreneurs. Journal of Economics \& Management Strategy, 10: 301-330.

Brocas, I., \& Carrillo, J. D. 2004. Entrepreneurial boldness and excessive investment. Journal of Economics \& Management Strategy, 13: 321-350.

Brown, K. C. 1974. A note on the apparent bias of net revenue estimates for capital investment projects. Journal of Finance, 29: 1215-1216.

Buehler, R., Griffin, D., \& MacDonald, H. 1997. The role of motivated reasoning in optimistic time predictions. Personality and Social Psychology Bulletin, 23: 238-247.

Buehler, R., Griffin, D., \& Ross, M. 1994. Exploring the "planning fallacy": Why people underestimate their task completion times. Journal of Personality and Social Psychology, 67: 366-381.

Busenitz, L. W., \& Barney, J. B. 1997. Differences between entrepreneurs and managers in large organizations: Biases and heuristics in strategic decision-making. Journal of Business Venturing, 12: 9-30.

Cable, D. M., \& Shane, S. 1997. A prisoner's dilemma approach to entrepreneur-venture capitalist relationships. Academy of Management Review, 22: 142-176.

Camerer, C., \& Lovallo, D. 1999. Overconfidence and excess entry: An experimental approach. American Economic Review, 89: 306-318. 
Cassar, G. 2006. Entrepreneurial opportunity costs and intended venture growth. Journal of Business Venturing, 21: 610-632.

Cassar, G., \& Gibson, B. 2007. Forecast rationality in small firms. Journal of Small Business Management, 45: 283-302.

Conway, M., \& Ross, M. 1984. Getting what you want by revising what you had. Journal of Personality and Social Psychology, 47: 738-748.

Cooper, A. C., Dunkelberg, W. C., \& Woo, C. Y. 1988. Entrepreneurs' perceived chances for success. Journal of Business Venturing, 3: 97-108.

Delmar, F., \& Shane, S. 2003. Does business planning facilitate the development of new ventures? Strategic Management Journal, 24: 1165-1185.

Durand, R. 2003. Predicting a firm's forecasting ability: The roles of organizational illusion of control and organizational attention. Strategic Management Journal, 24: 821-838.

Evans, D. S., \& Jovanovic, B. 1989. An estimated model of entrepreneurial choice under liquidity constraints. Journal of Political Economy, 97: 808-827.

Evans, D. S., \& Leighton, L. S. 1989. Some empirical aspects of entrepreneurship. American Economic Review, 79: 519-535.

Flyvbjerg, B. 2004. Procedures for dealing with optimism bias in transport planning: Guidance document. London: British Department for Transport.

Forbes, D. P. 2005. Are some entrepreneurs more overconfident than others? Journal of Business Venturing, 20: 623-640.

Gartner, W. B., Shaver, K. G., Carter, N. M., \& Reynolds, P. D. (Eds.) 2004. Handbook of entrepreneurial dynamics: The process of business creation. Thousand Oaks, CA: Sage.

Gervais, S., Heaton, J. B., \& Odean, T. 2005. Overconfidence, investment policy, and manager welfare. Working paper.

Gimeno, J., Folta, T. B., Cooper, A. C., \& Woo, C. Y. 1997. Survival of the fittest? Entrepreneurial human capital and the persistence of underperforming firms. Administrative Science Quarterly, 35: 504-529.

Golden, B. R. 1992. The past is the past: Or is it? The use of retrospective accounts as indicators of past strategy. Academy of Management Journal, 35: 848-860. 
Griffin, D. W., Dunning, D., \& Ross, L. 1990. The role of construal processes in overconfident predictions about the self and others. Journal of Personality and Social Psychology, 59: 1128-1139.

Hastie, R., \& Dawes, R. M. 2001. Rational choice in an uncertain world: The psychology of judgment and decision making. Thousand Oaks, CA: Sage.

Harrison, R. J., \& March, J. G. 1984. Decision making and postdecision surprises. Administrative Science Quarterly, 29: 26-42.

Hawkins, S. A., \& Hastie, R. 1990. Hindsight: Biased judgments of past events after the outcomes are known. Psychological Bulletin, 107: 311-327.

Hayward, M. L. A., Shepherd, D. A., \& Griffin, D. 2006. A hubris theory of entrepreneurship. Management Science, 52: 160-172.

Heath, C., \& Gonzalez, R. 1995. Interaction with others increases decision confidence but not decision quality: Evidence against information collection views of interactive decision making. Organizational Behavior and Human Decision Processes, 61: 305-326.

Heaton, J. B. 2002. Managerial optimism and corporate finance. Financial Management, 31: 3345.

Henry, R. A. 1994. The effects of choice and incentives on the overestimation of future performance. Organizational Behavior and Human Decision Processes, 57: 210-225.

Hoch, S. J. 1984. Availability and interference in predictive judgment. Journal of Experimental Psychology: Learning, Memory, and Cognition, 10: 649-662.

Johnson, M. K. \& Sherman, S. J. 1990. Constructing and reconstructing the past and the future in the present. In E. T. Higgins \& R. M. Sorrentino (Eds.), Handbook of motivation and social cognition: Foundations of social behavior, vol. 2: 482-526. New York: Guilford Press.

Kahneman, D., \& Lovallo, D. 1993. Timid choices and bold forecasts: A cognitive perspective on risk taking. Management Science, 39: 17-31.

Kahneman, D., \& Tversky, A. 1973. On the psychology of prediction. Psychological Review, 80: 237-251.

Kahneman, D., \& Tversky, A. 1979. Intuitive predictions: Biases and corrective procedures. In S. Makrdakis \& S. C. Wheelwright (Eds.), TIMS studies in management science, vol. 12, 313-327. New York: North Holland.

Kahneman, D., Slovic, P., \& Tversky, A. 1982. Judgment under uncertainty: Heuristics and biases. New York: Cambridge University Press. 
Kahneman, D., \& Tversky, A. 1995. Conflict resolution: A cognitive perspective. In K. Arrow, R. H. Mnookin, L. Ross, A. Tversky, \& R. Wilson (Eds.),. Barriers to conflict resolution, 44-61. New York: Norton.

Kennedy, P. 2003. A guide to econometrics (5th ed.). Cambridge, MA: MIT Press.

Kruger, J., \& Dunning D. 1999. Unskilled and unaware of it: How difficulties in recognizing one's own incompetence lead to inflated self-assessments. Journal of Personality and Social Psychology, 77: 1121-1134.

Koriat, A., Lichtenstein, S., \& Fischhoff, B. 1980. Reasons for confidence. Journal of Experimental Psychology: Human Learning and Memory, 6: 107-118.

Larwood, L., \& Whittaker, W. 1977. Managerial myopia: Self-serving biases in organizational planning. Journal of Applied Psychology, 62: 94-198.

Levi, A. S., \& Pryor, J. B. 1987. Use of the availability heuristic in probability estimates of future events: The effects of imagining outcomes versus imagining reasons. Organizational Behavior and Human Decision Processes, 40: 219-234.

Lovallo, D., \& Kahneman, D. 2003. Delusions of success. Harvard Business Review, 81(7): 5663.

Lowe, R. A., \& Ziedonis. A. A. 2006. Overoptimism and the performance of entrepreneurial firms. Management Science, 52: 173-186.

Maddala, G. S. 1983. Limited-dependent and qualitative variables in econometrics. New York: Cambridge University Press.

Malmendier, U. \& Tate, G. 2005a. CEO overconfidence and corporate investment. Journal of Finance, 60: 2661-2700.

Malmendier, U. \& Tate, G. 2005b. Does overconfidence affect corporate investment? CEO overconfidence measures revisited. European Financial Management, 11: 649-659.

McCarthy, A. M., Schoorman, F. D., \& Cooper, A. C. 1993. Reinvestment decisions by entrepreneurs: Rational decision-making or escalation of commitment? Journal of Business Venturing, 8: 9-24.

McNamara, G., \& Bromiley, P. 1997. Decision making in an organizational setting: Cognitive and organizational influences on risk assessment in commercial lending. Academy of Management Journal, 40: 1063-1088.

Moskowitz, T. J., \& Vissing-Jorgensen, A. 2002. The returns to entrepreneurial investment: A private equity premium puzzle. American Economic Review, 92: 745-778. 
Puri, M., \& Robinson, D. T. 2005. Optimism and economic choice. Working paper.

Schwarz, N. 1994. Judgment in a social context: Biases, shortcomings and the logic of conversation. In M. P. Zanna (Ed.), Advances in experimental social psychology, vol. 26, 123-126. New York: Academic Press.

Schweiger, D., Sandberg, W., \& Ragan, J. 1986. Group approaches for improving strategic decision making: A comparative analysis of dialectic inquiry, devil's advocacy, and consensus. Academy of Management Journal, 5: 111-128.

Sedor, L. M. 2002. An explanation for unintentional optimism in analysts' earnings forecasts. The Accounting Review, 77: 731-753.

Shane, S., \& Delmar, F. 2004. Planning for the market: Business planning before marketing and the continuation of organizing efforts. Journal of Business Venturing, 19: 767-785.

Shane, S., \& Venkataraman, S. 2000. The promise of entrepreneurship as a field of research. Academy of Management Review, 25: 217-226.

Simon, H. A. 1955. A behavioral model of rational choice. Quarterly Journal of Economics, 69: 99-118.

Simon, M., \& Houghton, S. M. 2003. The relationship between overconfidence and the introduction of risky products: Evidence from a field study. Academy of Management Journal, 46: 139-149.

Simon, M., Houghton, S. M., \& Aquino, K. 1999. Cognitive biases, risk perception, and venture formation: How individuals decide to start companies. Journal of Business Venturing, 15: 113-134.

Taylor, S. E., \& Brown, J. D. 1988. Illusion and well-being: A social psychological perspective on mental health. Psychological Bulletin, 103: 193-210.

Taylor, S. E., \& Gollwitzer, P. M. 1995. Effects of mindset on positive illusions. Journal of Personality and Social Psychology, 69: 213-226.

Tversky, A., \& Kahneman, D. 1974. Judgments under uncertainty: Heuristics and biases, Science, 185, 1124-1131.

Tversky, A., Sattath, S., \& Slovic, P. 1988. Contingent weighting in judgment and choice, Psychological Review, 95: 371-384.

Van der Steen, E. 2004. Rational overoptimism (and other biases). American Economic Review, 94:1141-1151. 
Weick, K. E. 1995. Sensemaking in organizations. Thousand Oaks, CA: Sage.

Weinstein, N. 1980. Unrealistic optimism about future life events. Journal of Personality and Social Psychology, 36: 806-820.

Wooldridge, J. M. 2003. Introductory econometrics: A modern approach. Mason, OH: SouthWestern.

Zacharakis, A. L., \& Shepherd, D. A. 2001. The nature of information and overconfidence on venture capitalists' decision making. Journal of Business Venturing, 16: 311-332.

Zhao, H., Seibert, S. E., \& Hills, G. E. 2005. The mediating role of self-efficacy in the development of entrepreneurial intentions. Journal of Applied Psychology, 90: 12651272. 
TABLE 1

Future Status of Nascent Venture Activity

\begin{tabular}{lcr}
\hline \multicolumn{1}{c}{ Future Status Description } & Status & n \\
\hline Not operating business after 60 months & Not Operating & 4 \\
Given up on start activity & Not Operating & 168 \\
Business was shut down before 60 months & Not Operating & 29 \\
Team members operating business that was given up by respondent & Operating & 20 \\
Operating business at last phone interview & Operating & 165 \\
Total & & 386 \\
\hline
\end{tabular}


TABLE 2

Descriptive Statistics and Correlations ${ }^{\mathrm{a}}$

\begin{tabular}{|c|c|c|c|c|c|c|c|c|c|c|c|c|c|c|c|c|}
\hline Variables & $\mathbf{n}$ & Mean & s.d. & Median & 1 & 2 & 3 & 4 & 5 & 6 & 7 & 8 & 9 & 10 & 11 & 12 \\
\hline 1. Operational over-optimism & 385 & $33.17 * *$ & 52.78 & $10.00 * *$ & & & & & & & & & & & & \\
\hline 2. Sales over-optimism & 50 & $0.17 *$ & 0.53 & $0.25^{*}$ & .20 & & & & & & & & & & & \\
\hline 3. Employment over-optimism & 46 & $0.15 \dagger$ & 0.57 & 0.00 & -.22 & $.49 *$ & & & & & & & & & & \\
\hline 4. Formal business planning & 380 & 0.16 & 0.37 & 0.00 & -.02 & .03 & -.13 & & & & & & & & & \\
\hline 5. Financial projections & 385 & 0.33 & 0.47 & 0.00 & -.03 & $.37 * *$ & -.21 & .38 & & & & & & & & \\
\hline 6. Education & 386 & 3.22 & 1.28 & 3.00 & -.07 & .04 & -.15 & .06 & .08 & & & & & & & \\
\hline 7. Gender & 386 & 0.51 & 0.50 & 1.00 & .05 & -.12 & .03 & $-.13 *$ & $-.17 * *$ & .05 & & & & & & \\
\hline 8. Industry experience & 386 & 9.18 & 10.34 & 5.00 & -.05 & -.01 & $.31 *$ & $.16^{* *}$ & .03 & .06 & $-.10 \dagger$ & & & & & \\
\hline 9. Product development & 376 & 0.63 & 0.38 & 0.67 & $-.13 *$ & -.17 & -.08 & .05 & .05 & .03 & .01 & $.09 \dagger$ & & & & \\
\hline 10. Promotion & 386 & 0.57 & 0.50 & 1.00 & $-.13 *$ & -.00 & .03 & $.11 *$ & .15 & .06 & -.05 & .07 & $.40 * *$ & & & \\
\hline 11. Raw inputs & 386 & 0.73 & 0.45 & 1.00 & -.11 & -.05 & -.11 & -.01 & .12 & -.01 & .07 & .00 & $.34 * *$ & $.36^{* *}$ & & \\
\hline 12. Capital inputs & 386 & 0.53 & 0.50 & 1.00 & $-.15 * *$ & .09 & .20 & .01 & .12 & -.05 & -.08 & .07 & $.23 * *$ & $.23 * *$ & $.35^{* *}$ & \\
\hline 13. Money received & 386 & 0.41 & 0.49 & 0.00 & $-.18 * *$ & -.21 & -.01 & .07 & .07 & .03 & .05 & .08 & $.44 * *$ & $.38 * *$ & $.29 * *$ & $.35 * *$ \\
\hline
\end{tabular}

$\dagger p<.10 ; * p<.05 ; * * p<.01$ 
TABLE 3

Results of GMM Regression Analysis of Operational Expectations and Over-Optimism ${ }^{\text {a }}$

\begin{tabular}{|c|c|c|c|c|c|c|c|c|c|c|c|}
\hline \multirow[b]{2}{*}{ Variables } & \multicolumn{5}{|c|}{ Expectation of Operation } & \multicolumn{6}{|c|}{ Operational Over-Optimism } \\
\hline & Model 1 & \multicolumn{2}{|c|}{ Model 2} & \multicolumn{2}{|c|}{ Model 3} & \multicolumn{2}{|c|}{ Model 4} & \multicolumn{2}{|c|}{ Model 5} & \multicolumn{2}{|c|}{ Model 6} \\
\hline Intercept & $79.40 * * *(1.65)$ & $82.42 * * *$ & $(5.05)$ & $81.42^{* * *}$ & $(5.10)$ & $34.13 * * *$ & $(3.50)$ & $58.27 * * *$ & $(10.24)$ & $58.11 *$ & $*(10.34)$ \\
\hline Formal business planning & $9.90 * * *(2.85)$ & & & $8.42 * *$ & $(2.91)$ & -1.48 & $(7.40)$ & & & 0.97 & $(7.40)$ \\
\hline Financial projections & $-0.44 \quad(2.91)$ & & & 0.11 & $(3.11)$ & -4.60 & $(6.07)$ & & & 0.22 & $(6.10)$ \\
\hline Education & & $-2.68 *$ & $(1.12)$ & $-2.75^{*}$ & $(1.14)$ & & & -3.01 & $(2.19)$ & -3.03 & $(2.22)$ \\
\hline Gender & & 1.66 & $(2.59)$ & 2.45 & $(2.69)$ & & & 6.22 & $(5.60)$ & 6.34 & $(5.70)$ \\
\hline Industry experience & & $0.25 *$ & $(0.11)$ & $0.20 \dagger$ & $(0.11)$ & & & -0.19 & $(0.26)$ & -0.19 & $(0.27)$ \\
\hline Product development & & 2.63 & $(3.93)$ & 2.69 & $(3.92)$ & & & -1.39 & $(8.67)$ & -1.37 & $(8.73)$ \\
\hline Promotion & & 5.55 & $(3.03)$ & 5.00 & $(3.03)$ & & & -3.69 & $(6.52)$ & -3.78 & $(6.57)$ \\
\hline Raw inputs & & -2.04 & $(3.14)$ & -1.78 & $(3.16)$ & & & -4.28 & $(7.20)$ & -4.27 & $(7.28)$ \\
\hline Capital inputs & & -0.37 & $(2.98)$ & -0.12 & (2.99) & & & $-10.27 \dagger$ & $(6.16)$ & -10.25 & $(6.22)$ \\
\hline Money received & & 1.93 & $(2.93)$ & 1.48 & $(2.93)$ & & & $-14.28 *$ & $(6.41)$ & $-14.33 *$ & $(6.45)$ \\
\hline Wald $\chi^{2}$ & $14.63 * *$ & $18.17^{*}$ & & $31.99 * * *$ & & 0.81 & & $27.35 * * *$ & & $27.37 *$ & \\
\hline $\mathrm{R}^{2}$ & 0.02 & 0.05 & & 0.06 & & 0.00 & & 0.06 & & 0.06 & \\
\hline $\mathrm{n}$ & 368 & 368 & & 368 & & 368 & & 368 & & 368 & \\
\hline
\end{tabular}

\footnotetext{
${ }^{\mathrm{a}}$ Standard errors are reported in parentheses.

$\dagger p<.10$

$* p<.05$

$* * p<.01$

$* * * p<.001$, two tailed tests
} 
TABLE 4

Results of GMM Regression Analysis of One-Year Sales and Employment Over-Optimism ${ }^{\text {a }}$

\begin{tabular}{|c|c|c|c|c|c|c|c|c|c|c|c|c|}
\hline \multirow{3}{*}{$\begin{array}{ll} & \text { Variables } \\
\text { Intercept } & \end{array}$} & \multicolumn{6}{|c|}{ Sales Over-Optimism } & \multicolumn{6}{|c|}{ Employment Over-Optimism } \\
\hline & \multicolumn{2}{|c|}{ Model 1} & \multicolumn{2}{|c|}{ Model 2} & \multicolumn{2}{|c|}{ Model 3} & \multicolumn{2}{|c|}{ Model 4} & \multicolumn{2}{|c|}{ Model 5} & \multicolumn{2}{|c|}{ Model 6} \\
\hline & $0.16 \dagger$ & $(0.08)$ & 0.00 & $(0.09)$ & 0.21 & $(0.33)$ & 0.21 & $(0.12)$ & 0.26 & $(0.12)$ & 0.00 & $(0.52)$ \\
\hline Formal business planning & 0.04 & $(0.18)$ & & & & & -0.15 & $(0.16)$ & & & & \\
\hline Financial projections & & & $0.40 * *$ & $(0.14)$ & $0.44^{*}$ & $(0.18)$ & & & -0.23 & $(0.16)$ & -0.20 & $(0.16)$ \\
\hline Education & & & & & -0.03 & $(0.07)$ & & & & & 0.00 & $(0.08)$ \\
\hline Gender & & & & & 0.00 & $(0.16)$ & & & & & -0.03 & $(0.17)$ \\
\hline Industry experience & & & & & -0.00 & $(0.01)$ & & & & & 0.01 & $(0.01)$ \\
\hline Product development & & & & & -0.14 & $(0.27)$ & & & & & -0.14 & $(0.40)$ \\
\hline Promotion & & & & & 0.12 & $(0.15)$ & & & & & 0.07 & $(0.25)$ \\
\hline Raw inputs & & & & & -0.01 & $(0.22)$ & & & & & -0.14 & $(0.32)$ \\
\hline Capital inputs & & & & & 0.15 & $(0.24)$ & & & & & $0.41 \dagger$ & $(0.23)$ \\
\hline Money received & & & & & $-0.30 \dagger$ & $(0.16)$ & & & & & -0.10 & $(0.18)$ \\
\hline Wald $\chi^{2}$ & 0.04 & & $7.88^{* *}$ & & $23.79 * *$ & & 0.85 & & 1.99 & & 12.99 & \\
\hline $\mathrm{R}^{2}$ & 0.00 & & 0.14 & & 0.24 & & 0.02 & & 0.04 & & 0.23 & \\
\hline $\mathrm{n}$ & 50 & & 50 & & 50 & & 46 & & 46 & & 46 & \\
\hline
\end{tabular}

\footnotetext{
${ }^{a}$ Standard errors are reported in parentheses.

$\dagger p<.10$

$* p<.05$

$* * p<.01$

$* * * p<.001$, two tailed tests.
} 